Review

\title{
Surface Modification of Hematite Photoanodes for Improvement of Photoelectrochemical Performance
}

\author{
Lifei $\mathrm{Xi}^{1}{ }^{1}$ and Kathrin M. Lange ${ }^{1,2, *}$ \\ 1 Operando Characterization of Solar Fuel Materials (EE-NOC), Helmholtz-Zentrum Berlin für Materialien \\ und Energie, Albert-Einstein-Str. 15, 12489 Berlin, Germany; lifei.xi@helmholtz-berlin.de \\ 2 Physikalische Chemie, Universität Bielefeld, Universitätsstr. 25, 33615 Bielefeld, Germany \\ * Correspondence: kathrin.lange@helmholtz-berlin.de; Tel.: +49-(030)-8062-15059
}

Received: 26 September 2018; Accepted: 20 October 2018; Published: 26 October 2018

\begin{abstract}
Solar water splitting is a promising method for producing renewable fuels. Thermodynamically, the overall water splitting reaction is an uphill reaction involving a multiple electron transfer process. The oxygen evolution reaction (OER) has been identified as the bottleneck process. Hematite $\left(\alpha-\mathrm{Fe}_{2} \mathrm{O}_{3}\right)$ is one of the best photoanode material candidates due to its band gap properties and stability in aqueous solution. However, the reported efficiencies of hematite are notoriously lower than the theoretically predicted value mainly due to poor charge transfer and separation ability, short hole diffusion length as well as slow water oxidation kinetics. In this Review Article, several emerging surface modification strategies to reduce the oxygen evolution overpotential and thus to enhance the water oxidation reaction kinetics will be presented. These strategies include co-catalysts loading, photoabsorption enhancing (surface plasmonic metal and rare earth metal decoration), surface passivation layer deposition, surface chemical etching and surface doping. These methods are found to reduce charge recombination happening at surface trapping states, promote charge separation and diffusion, and accelerate water oxidation kinetics. The detailed surface modification methods, surface layer materials, the photoelectrochemical (PEC) performances including photocurrent and onset potential shift as well as the related proposed mechanisms will be reviewed.
\end{abstract}

Keywords: hematite; photoelectrochemical; water oxidation; surface modification; flatband potential; onset potential; photocurrent; kinetics; photoanode

\section{Introduction}

Solar water splitting is a technology that can potentially produce a clean, environmentally friendly and cheap hydrogen fuel by using renewable energy sources. It allows to collect and store solar energy in chemical bonds and thus to overcome the challenge of daily and seasonal variability in renewable energy [1]. However, even though the electrolysis of water is considered to be one of the easiest methods to obtain hydrogen [2], the required high overpotentials still hinder a large scale application. Thermodynamically, the overall water splitting reaction is an uphill reaction $(\Delta \mathrm{G}=237 \mathrm{~kJ} / \mathrm{mol})$ involving a multiple electron transfer process [3]. The oxygen evolution reaction (OER) has been identified as the bottleneck for the conversion process because of its large requisite overpotential [4]. Hematite $\left(\alpha-\mathrm{Fe}_{2} \mathrm{O}_{3}\right)$ is predicted to be an efficient photoelectrode material due to its moderate band gap $(\mathrm{Eg}=\sim 1.9-2.2 \mathrm{eV})$, chemical stability, abundance, non-toxicity and low cost [5-7]. A photocurrent of $12.5 \mathrm{~mA} \mathrm{~cm}{ }^{-2}$ under AM1.5 solar light irradiation is predicted [8]. Although a respectable photocurrent onset potential $\left(\mathrm{V}_{\text {onset }}\right.$ ) of $<0.8 \mathrm{~V}$ vs. reverse hydrogen electrode (RHE) and photocurrents of $3.2 \mathrm{~mA} \mathrm{~cm}^{-2}$ under AM1.5 solar light irradiation have been achieved [9], the reported efficiencies are notoriously lower than the theoretical value. It is worth mentioning that the $V_{\text {onset }}$ is the shift or deviation from the flatband potential $\left(\mathrm{V}_{\mathrm{fb}}\right)$. The flatband potential $\left(\mathrm{V}_{\mathrm{fb}}\right)$ is the potential 
required to bring back the semiconductor band edges to their flat band position from the bending position at the hematite/electrolyte junction. $\mathrm{V}_{\mathrm{fb}}$ is an intrinsic property of hematite and one of the key parameters used in the evaluation of the photocatalytic activity of the photoelectrode and mainly affects the probability of charge recombination. The $\mathrm{V}_{\mathrm{fb}}$ of hematite is around $0.4 \mathrm{~V}$ vs. RHE [9]. The quantity $V_{\text {onset }}-V_{f b}$ is generally referred to as overpotential for the solar water oxidation. Thus, a smaller value for $\left(\mathrm{V}_{\mathrm{onset}}-\mathrm{V}_{\mathrm{fb}}\right)$ indicates a lower external bias (overpotential) required and hence implies a better photocatalytic activity. The poor performance of hematite is predominantly due to the poor charge transfer and separation ability, the short lifetime of the charge carriers $(<10 \mathrm{ps})$, accompanying a short hole diffusion length $(2-4 \mathrm{~nm})$ [10], as well as slow water oxidation kinetics. Further improvements are highly demanded before the full potential of hematite can be reached for artificial photosynthesis devices.

To improve the solar water splitting efficiency of hematite materials a nanostructured morphology can be adopted, for example, nanorods or nanowire arrays [11], ultra-thin films [12], or thin films grown on three-dimensional (3D) nanotextured conducting substrates [13]. However, the nanostructured morphology strategy cannot speed up the slow water oxidation process, which limits the solar to fuel energy conversion efficiency. Surface modification of the photoanode with a co-catalyst, loading a surface passivation layer, or doing surface chemical corrosion were found to improve the overall system efficiency [14]. These methods may reduce charge recombination occurring at surface trapping states, promote separation and diffusion of carrier species and accelerate water oxidation kinetics [15]. Recently, forming heterojunctions at the nanoscale by coupling hematite to a second semiconductor has been evidenced as an effective way to engineer the band structure for enhanced optical absorption and promoting charge separation [15].

\section{Surface Modification Strategies}

In order to drive the water splitting reaction, the energy bands of the photoabsorber need to be properly aligned. Considering the invariable losses, the interfacial charge transfers and overpotentials for the molecular hydrogen and oxygen formation, a band gap of $\sim 3.0 \mathrm{eV}$ is required to make the reaction energetically favorable if using a single junction PEC device. Further, the band positions relative to the redox potentials of the electrolyte need to be considered. Figure 1a shows the energy levels of conduction band (CB) and valence band (VB) of hematite in respect to the reverse hydrogen electrode (RHE) and vacuum level ( $\left.E_{\mathrm{vac}}\right)$. It can be seen that hematite has a more positive CB edge than the hydrogen reduction potential, thus an external electrical bias is required to split water. This is the main reason for the required overpotential [1] as well as the positive $V_{\text {onset. Bulk doping is }}$ an effective way to shift the $\mathrm{V}_{\mathrm{fb}}$ and $\mathrm{V}_{\text {onset }}$ by changing the conduction and valence band levels [16]. However, details of bulk doping are beyond the scope of this review. Interested readers are referred to the review references $[17,18]$. Slow water oxidation kinetics are considered to be another reason for the positive $V_{\text {onset }}$. In order to enhance the water oxidation kinetics and reduce the applied potential, various surface modification strategies have been developed for hematite photoanodes. The effect of surface modification on a photoanode is schematically shown in Figure 1b. It can be seen that surface modification can reduce the $\mathrm{V}_{\text {onset }}$ for water oxidation, increase the photocurrent and, in some cases, reduce the $\mathrm{V}_{\mathrm{fb}}$. However, the effects and mechanisms of these surface modification strategies are quite different. For example, a non-catalytic surface passivation layer may reduce hematite surface charge trapping defects which reduces the electron-hole recombination rate, while a co-catalyst may mainly assist hole transport from the surface of hematite to the electrolyte [19]. In the next sections, various surface modification methods will be presented together with the resulting effects and proposed mechanisms. 


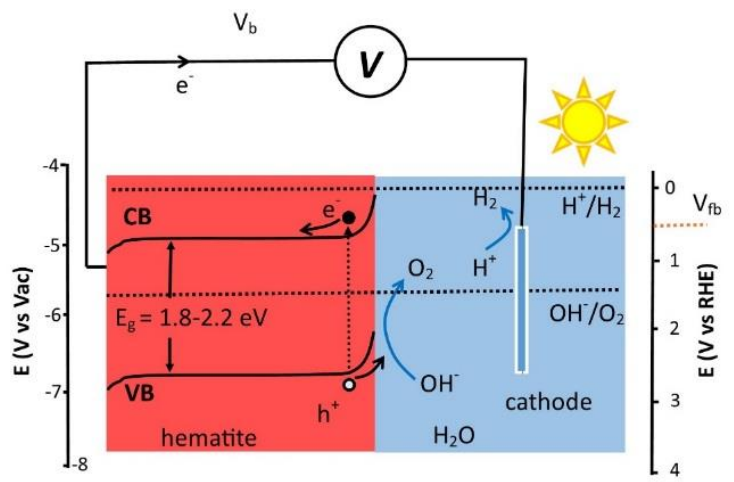

(a)

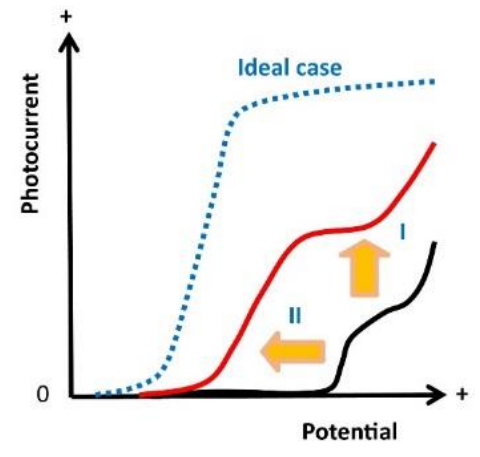

(b)

Figure 1. (a) Energy diagram for solar water splitting with a hematite photoanode performing the oxygen evolution reaction (OER) and a cathode carrying out the hydrogen evolution reaction (HER). The hematite bandgap $\left(\mathrm{E}_{\mathrm{g}}\right)$, the flatband potential $\left(\mathrm{V}_{\mathrm{fb}}\right)$, the applied bias $\left(\mathrm{V}_{\mathrm{b}}\right)$, and the redox potential of water are indicated; (b) photoelectrochemical performance improvement of the hematite photoanode via surface modification. Arrow I indicates a photocurrent increase, arrow II indicates a photocurrent onset potential shift. The blue dotted line shows an idealized photocurrent vs. potential (I-V) of the hematite photoanode. The red line shows the I-V curve after surface modification while the back curve shows that of as prepared.

\subsection{Co-Catalyst}

In the past few years, the studies of co-catalyst loading including noble metal oxides and earth abundant metal oxides attracted great attention. Co-catalysts may promote separation and diffusion of charge carriers, thus decrease the recombination rate, reduce the overpotential required for the OER to occur, enhance the activity in the redox reactions, and in some cases provide a broadened absorption range. In this section, we will start with a review of noble metal based co-catalyst surface modification.

\subsubsection{Noble Metal Based Co-Catalysts}

As it is well known that the PEC efficiency is limited by the sluggish four-electron water oxidation kinetics [14,15], a great effort has been made to find a highly active and stable OER catalyst compatible with the harsh working conditions, e.g., a wide range of $\mathrm{pH}$ values or a high anodic potential. Noble metal oxides are the best available compromise between OER activity and stability at the moment. Several noble metal based co-catalysts have been developed to modify the hematite photoanode surface (see Table 1). These include $\mathrm{IrO}_{2}$ [9], $\mathrm{IrO}_{\mathbf{x}}$ [20,21], $\mathrm{RuO}_{2}$ [22], $\mathrm{RuO}_{\mathbf{x}}$ [23,24], $\mathrm{Rh}(\mathrm{OH})_{x}$ [25] and $\mathrm{Pt}$ [26]. For example, surface modification of nanostructured hematite photoanodes with $2 \mathrm{~nm}$ $\mathrm{IrO}_{2}$ nanoparticles resulted in a $200 \mathrm{mV}$ cathodic shift in the $\mathrm{V}_{\text {onset }}$ and an increase in the plateau photocurrent from 3.45 to $3.75 \mathrm{~mA} \mathrm{~cm}^{-2}$ [9]. Even with this success, they still found the $\mathrm{V}_{\text {onset }}$ of around $400 \mathrm{mV}$ more positive than the $\mathrm{V}_{\mathrm{fb}}$, suggesting that surface states with mid-band-gap energies cause the carrier recombination in hematite. This further emphasizes that the continued optimization of both the nanostructure and the surface modification can ultimately achieve the full potential of solar water splitting using hematite. An electrodeposited $\mathrm{IrO}_{\mathrm{x}}$ layer, which serves as a highly capacitive layer was reported to catalyze water oxidation by enhancing charge separation and storing photo-generated holes in hematite. This gave rise to a cathodic shift of $300 \mathrm{mV}$ (see Figure 2) [20]. Similarly, $\mathrm{Rh}(\mathrm{OH})_{x}$ formed from the $\mathrm{Na}_{3} \mathrm{RhCl}_{6} \cdot 12 \mathrm{H}_{2} \mathrm{O}$ alkaline solution was also used to modify the hematite photoanodes, which resulted in a significant decrease of up to $200 \mathrm{mV}$ in the overpotential due to efficient hole transfer from hematite to $\mathrm{Rh}(\mathrm{OH})_{x}$ [25]. Hematite modified with oxidized Pt species also shows a greatly enhanced photocurrent density for water splitting, mainly due to improved charge transfer and retarded carrier recombination [26]. Even though these noble metal or noble metal oxide decorated hematite photoanodes show a significant overpotential reduction and high stability, it has to be considered that noble metals are expensive and not abundant elements, making them unsuitable for 
large-scale water splitting applications. Therefore, it is an essential step towards practical applications to find a cheap, efficient and scalable OER co-catalyst. In the next section, several earth abundant OER co-catalyst will be reviewed.

Table 1. List of noble metal co-catalysts used for surface modification on hematite nanostructures. Note: ${ }^{\mathrm{a}}$ vs. NHE, ${ }^{\mathrm{b}}$ at $0.72 \mathrm{~V}$ vs. NHE $\left(200 \mathrm{~W} \mathrm{Xe,} 150 \mathrm{~mW} \cdot \mathrm{cm}^{-2}\right),{ }^{\mathrm{c}} 500 \mathrm{~W}$ xenon illumination.

\begin{tabular}{|c|c|c|c|c|c|c|}
\hline Noble Metal & Preparation & Electrolyte & $\begin{array}{c}\text { Onset } \\
\text { Potential } \\
\left(V_{\text {RHE }}\right)\end{array}$ & $\begin{array}{c}\text { Onset } \\
\text { Potential } \\
\text { shift }(\mathrm{mV})\end{array}$ & $\begin{array}{c}\text { Photocurrent at } \\
1.23 \mathrm{~V}_{\mathrm{RHE}} \\
\left(\mathrm{mA} \mathrm{cm}^{-2}\right)\end{array}$ & Ref \\
\hline $\mathrm{IrO}_{2}$ & Electrophoresis & $1 \mathrm{M} \mathrm{NaOH}$ & 0.8 & 200 & $\sim 3.2$ & [9] \\
\hline $\mathrm{IrO}_{\mathrm{x}}$ & Electrodeposition & $0.1 \mathrm{M} \mathrm{KP}_{\mathrm{i}}(\mathrm{pH} 7)$ & $\sim 1.1$ & 300 & 0.2 & {$[20]$} \\
\hline $\mathrm{IrO}_{\mathrm{x}}$ & Photoelectrodeposition & $\begin{array}{c}0.1 \mathrm{M} \mathrm{KNO}_{3} \\
(\mathrm{pH}=1.01)\end{array}$ & 0.6 & 250 & 0.66 & [21] \\
\hline $\mathrm{RuO}_{2}$ & Spray pyrolysis & $\begin{array}{c}0.2 \mathrm{M} \mathrm{NaOH} \\
\text { containing } 0.5 \mathrm{M} \\
\mathrm{Na}_{2} \mathrm{SO}_{4}(\mathrm{pH} 13)\end{array}$ & $0.22^{\mathrm{a}}$ & 120 & $\sim 0.68^{\mathrm{b}}$ & [22] \\
\hline Ru complex & Dip coating & $1 \mathrm{M} \mathrm{NaOH}$ & 0.72 & $\sim 100$ & $\sim 2.2$ & [23] \\
\hline Ru complex & Self-assembly & $\begin{array}{c}0.1 \mathrm{M} \\
\mathrm{KHC}_{8} \mathrm{H}_{4} \mathrm{O}_{4}-\mathrm{HCl} \\
\text { buffer (pH 3) }\end{array}$ & 0.7 & $\sim 200$ & $\sim 0.12$ & {$[24]$} \\
\hline $\mathrm{Rh}(\mathrm{OH})_{\mathrm{x}}$ & Precipitation & $1 \mathrm{M} \mathrm{NaOH}$ & $\sim 0.2$ & $\sim 300$ & $1.5^{\mathrm{c}}$ & [25] \\
\hline $\mathrm{Pt}$ & Sputtering & $0.1 \mathrm{M} \mathrm{NaOH}$ & 0.8 & No data & 0.638 & [26] \\
\hline
\end{tabular}

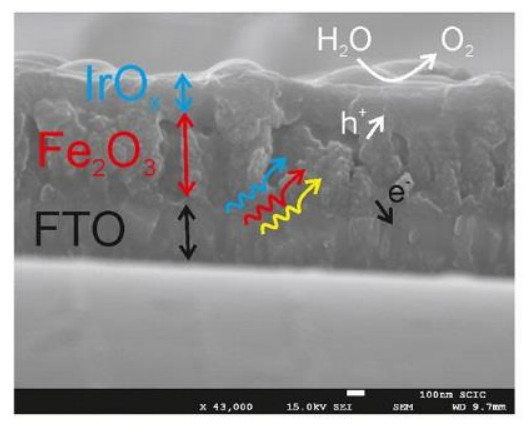

(a)

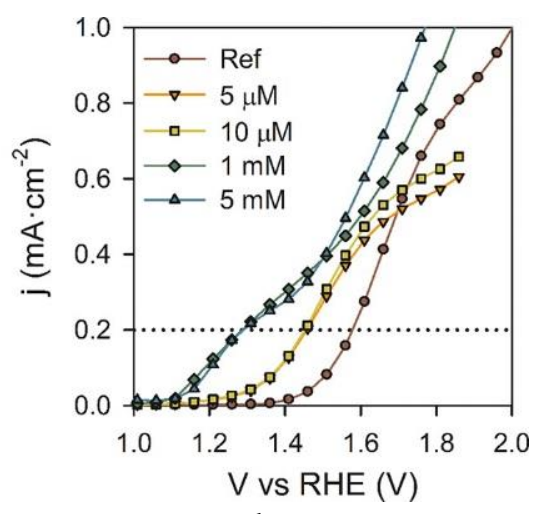

(b)

Figure 2. (a) Cross-section scanning electron microscope (SEM) image of fluorine doped tin oxide (FTO)/hematite and (b) steady-state I-V curves for bare hematite and after electrodeposition of pentamethylcyclopentadienyl $\left(\mathrm{C}^{*}\right)$ iridium(III) [C $\left.\mathrm{C}^{*} \mathrm{Ir}(\mathrm{III})\right]$ from differently concentrated solutions $(5 \mu \mathrm{M}, 10 \mu \mathrm{M}, 1 \mathrm{mM}$ and $5 \mathrm{mM})$. The lines are used as eye guides. Reprinted with permission from Reference [20], copyright (2013) American Chemical Society.

\subsubsection{Earth Abundant Metal Based Co-Catalysts}

Several earth abundant transition metal oxides based e.g., on $\mathrm{Co}$ and Ni have been used to modify photoanodes serving as stable co-catalyst that increases the turnover frequency (TOF) (see Table 2). Amorphous cobalt oxide $\left(\mathrm{CoO}_{\mathrm{x}}\right)$, named also $\mathrm{Co}-\mathrm{P}_{\mathrm{i}}$, which is electrodeposited by the oxidation of $\mathrm{Co}^{2+}$ ions to higher oxidation state in a neutral phosphate buffer solution, shows many favorable properties for application as water oxidation catalyst [27]. This includes its facile synthesis procedure, low cost, neutral operation condition ( $\mathrm{pH}$ 7), and a self-repairing mechanism. It has emerged as one of the most important OER co-catalysts and has been coupled with various photoanodes for effective PEC water splitting $[28,29]$. For example, an electrodeposited $\mathrm{Co}-\mathrm{P}_{\mathrm{i}}$ modified hematite photoanode shows a cathodic $\mathrm{V}_{\text {onset }}$ shift of $350 \mathrm{mV}$ [30]. Scanning electron microscope (SEM) studies imply that the catalyst layer deposited conformally onto the mesostructured hematite results in a large contact area at the interface of the composite photoanode. The modification of the hematite film with a conformal layer of co-catalyst is proposed to allow the separation of the processes of photon absorption and redox catalysis. 
This strategy has important and general ramifications for PEC hydrogen generation. The enhancement mechanism by $\mathrm{Co}-\mathrm{P}_{\mathrm{i}}$ incorporation was addressed in a systematic PEC and impedance spectroscopy study. The authors found that the Co- $\mathrm{P}_{\mathrm{i}}$ co-catalyst can efficiently collect and store photo-generated holes from the hematite electrode, thus, reduces the surface state recombination [31]. They also found that thicker $\mathrm{Co}-\mathrm{P}_{\mathrm{i}}$ films lead to increased water oxidation efficiencies which they attributed to the superior charge separation as well as the increased surface area. Besides Co- $\mathrm{P}_{\mathrm{i}}$, there are also other Co-based co-catalyst modified hematite studies. $\mathrm{Xi}$ et al. found that in situ incorporation of the $\mathrm{Co}_{3} \mathrm{O}_{4}$ during hydrothermal growth of hematite nanorod arrays greatly improves the photocurrent and the incident photon-to-current efficiency (IPCE) of hematite photoanodes (see Figure 3) [32]. We recently investigated photoelectrodeposited $\mathrm{CoB}_{\mathrm{i}}$ modified hematite nanorods combining PEC characterizations and in situ X-ray absorption spectroscopy (XAS) and found that the current density at $1.23 \mathrm{~V}$ of the bare hematite is $0.88 \mathrm{~mA} \mathrm{~cm}{ }^{-2}$ and increases to $1.12 \mathrm{~mA} \mathrm{~cm}^{-2}$ after $\mathrm{CoB}_{\mathrm{i}}$ co-catalyst modification ( $27 \%$ improvement) [4]. Operando XAS studies showed that photo-generated holes gradually oxidize Co species into higher oxidation states, e.g., $\mathrm{Co}^{4+}$, in the $\mathrm{CoB}_{\mathrm{i}}$ layer. The $\mathrm{CoB}_{\mathrm{i}}$ co-catalyst layer is suggested to mainly improve OER kinetics and also to reduce electron-hole recombination at the surface, resulting in photocurrent enhancement and a cathodic shift of $\mathrm{V}_{\text {onset. }}$. Similar, nickel based co-catalysts have been applied to hematite photoanodes for efficient solar water splitting [33-37]. For example, photochemically deposited $\mathrm{Ni}-\mathrm{B}_{\mathrm{i}}$ on hematite nanorods resulted in a cathodic shift of $>200 \mathrm{mV}$ in the $\mathrm{V}_{\text {onset }}$ for water oxidation and a 9.5 times photocurrent enhancement at $0.86 \mathrm{~V}$ vs. RHE compared to the pristine material [34]. The authors found that the Ni-Bi modified hematite photoanode showed an encouraging improvement of photocurrent density near the $V_{\mathrm{fb}}$ of hematite. In another study, atomic layer deposited (ALD) $\mathrm{Ni}(\mathrm{OH})_{2}$ led to a considerable reduction of the $\mathrm{V}_{\text {onset }}$ for water oxidation and a twofold improvement in photocurrent density at $1.23 \mathrm{~V}$ vs. RHE, which was effective for both the pristine and Ti-doped hematite photoanodes [36]. This enhanced performance is attributed to the improved charge separation with the ion-permeable $\mathrm{Ni}(\mathrm{OH})_{2}$ catalyst film.

Table 2. List of earth abundant metal based co-catalysts used for surface modification on hematite photoanodes.

\begin{tabular}{|c|c|c|c|c|c|c|c|}
\hline \multicolumn{2}{|c|}{ Transition Metal } & Catalyst Preparation & Electrolyte & $\begin{array}{c}\text { Onset } \\
\text { Potential } \\
\left(\mathrm{V}_{\mathrm{RHE}}\right)\end{array}$ & $\begin{array}{c}\text { Onset } \\
\text { Potential } \\
\text { shift }(\mathrm{mV})\end{array}$ & $\begin{array}{l}\text { Photocurrent } \\
\text { at } 1.23 \mathrm{~V}_{\mathrm{RHE}} \\
\left(\mathrm{mA} / \mathrm{cm}^{2}\right)\end{array}$ & Ref. \\
\hline \multirow{4}{*}{ Co } & $\mathrm{Co}_{3} \mathrm{O}_{4}$ & $\begin{array}{l}\text { in situ hydrothermal } \\
\text { growth }\end{array}$ & $1 \mathrm{M} \mathrm{NaOH}$ & 0.66 & 40 & 1.20 & [32] \\
\hline & $\mathrm{Co}-\mathrm{B}_{\mathrm{i}}$ & $\begin{array}{l}\text { photoelectrochemical } \\
\text { deposition }\end{array}$ & $\begin{array}{l}0.1 \mathrm{M} \mathrm{NaB}_{\mathrm{i}} \\
(\mathrm{pH} \mathrm{9.2)}\end{array}$ & 0.8 & 50 & 1.12 & {$[4]$} \\
\hline & Co-P $P_{i}$ & $\begin{array}{l}\text { electrochemical } \\
\text { deposition }\end{array}$ & $1 \mathrm{M} \mathrm{NaOH}$ & $\sim 0.8$ & 350 & 0.6 & [30] \\
\hline & Co- $P_{i}$ & $\begin{array}{l}\text { photoelectrochemical } \\
\text { deposition }\end{array}$ & $\begin{array}{c}0.1 \mathrm{M} \mathrm{KP} \\
\text { with }(\mathrm{pH} 6.9) \\
0.2 \mathrm{M} \mathrm{KCl}\end{array}$ & $\sim 0.9$ & $\sim 240$ & 0.4 & [31] \\
\hline \multirow{5}{*}{$\mathrm{Ni}$} & $\mathrm{Ni}(\mathrm{OH})_{2}$ & ALD & $1 \mathrm{M} \mathrm{KOH}$ & 0.9 & $\sim 300$ & 0.4 & [36] \\
\hline & $\mathrm{Ni}(\mathrm{OH})_{2}$ & Dip coating & $\begin{array}{l}1 \mathrm{M} \mathrm{KOH} \text { and } \\
0.1 \mathrm{M} \text { glucose }\end{array}$ & 0.7 & $\sim 200$ & 3.0 & [33] \\
\hline & $\mathrm{NiOOH}$ & Photoelectrodeposition & $1 \mathrm{M} \mathrm{NaOH}$ & 0.62 & 150 & 0.625 & [37] \\
\hline & $\mathrm{Ni}-\mathrm{B}_{\mathrm{i}}$ & Photodeposition & $1 \mathrm{M} \mathrm{NaOH}$ & 0.7 & $\sim 200$ & 0.55 & [34] \\
\hline & $\mathrm{Ni}-\mathrm{B}_{\mathrm{i}}$ & Photodeposition & $1 \mathrm{M} \mathrm{KB}_{\mathrm{i}}(\mathrm{pH} \sim 9.2)$ & 0.6 & 140 & 0.65 & [35] \\
\hline \multirow{4}{*}{ Others } & $\mathrm{MnO}_{\mathrm{x}}$ & ALD & $1 \mathrm{M} \mathrm{NaOH}$ & 0.1 .6 & $\sim 100$ & $<0.01$ & [38] \\
\hline & $\mathrm{FeNiOOH}$ & Electrodeposition & $1 \mathrm{M} \mathrm{NaOH}$ & 0.57 & 190 & 2.21 & [39] \\
\hline & $\begin{array}{l}\mathrm{ZnCo} \\
\mathrm{LDHs}\end{array}$ & Electrodeposition & $1 \mathrm{M} \mathrm{KOH}$ & $\sim 1.0$ & -100 & 1.73 & [40] \\
\hline & $\mathrm{NiCO}_{2} \mathrm{~S}_{4}$ & hydrothermal method & $1 \mathrm{M} \mathrm{KOH}$ & 0.51 & $\sim 330$ & 1.51 & [41] \\
\hline
\end{tabular}




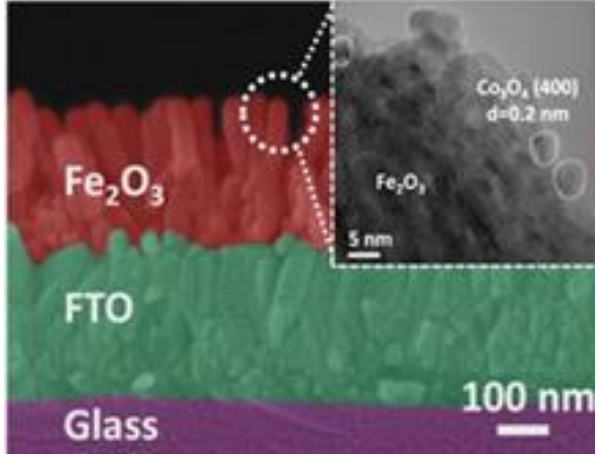

(a)

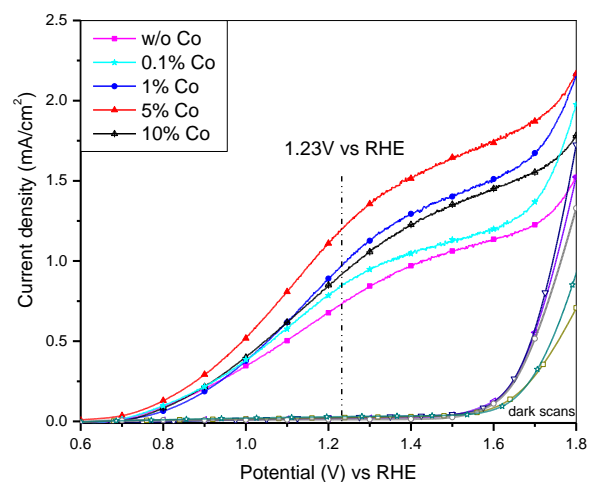

(b)

Figure 3. (a) Cross-section SEM image of hematite after annealing at $550{ }^{\circ} \mathrm{C}$ for $2 \mathrm{~h}$ and (b) I-V curves of hematite photoanodes with different amounts of $\mathrm{Co}^{2+}$ added to the precursor solution. Reprinted with permission from Reference [32], copyright (2012) American Chemical Society.

In the literature, other metal oxides, e.g., $\mathrm{MnO}_{x}$ [38], metal layered double (oxy)hydroxides [39,40] or sulfides [41] have been used as co-catalysts for hematite photoanodes to promote PEC performances for water splitting. For instance, electrodeposited FeNiOOH modified hematite resulted in a $190 \mathrm{mV}$ cathodic shift in the $\mathrm{V}_{\text {onset }}$ as well as a great increase in photocurrent density from 0.9 to $2.24 \mathrm{~mA} \mathrm{~cm}^{-2}$ [39]. The electrochemical impedance spectroscopy (EIS) results show that the FeNiOOH co-catalyst decreases the charge transfer barrier and reduces the OER barrier, leading to a cathodic shift of the $V_{\text {onset }}$.

It can be seen that surface modification with co-catalysts is an effective strategy to facilitate the water photo-oxidation reaction by accommodating excited electrons/holes via the oxidation of the metal element of the co-catalyst, assisting photo-generated hole transport from the hematite to the electrolyte and facilitating redox reaction kinetics. This results in a cathodic shift of $\mathrm{V}_{\text {onset }}$ and an enhancement in the photocurrent for the solar water oxidation.

\subsection{Enhancing Photoabsorption}

The poor PEC performance of hematite is mainly due to a short lifetime of photo-generated minority carriers (holes, $<10 \mathrm{ps}$ ) as well as a short diffusion length $(2-4 \mathrm{~nm})$ [10], resulting in significant non-radiative electron-hole recombination inside the hematite. The short diffusion length stands in conflict with the long absorption length of light (near the band edge in the micrometer regime) which greatly limits its PEC performance [14]. In recent years, several strategies including preparing ultrathin films, nanostructured hematite morphologies (nanorod, nanowire, nanopillar, nanotube and nanosheet), dual absorber heterostructures and 3D nanophotonic structured substrate/hematite photoanodes giving maximum possible photon absorption have been developed. Interested readers are referred to references [4-11,14,15,42]. Here, we will introduce two strategies, rare earth element and surface plasmonic metal decoration, to enhance photoabsorption of hematite photoanodes.

\subsubsection{Rare Earth Element Decoration}

Rare earth elements have attracted great attention in catalytic processes due to their optoelectronic properties arising from their unique electronic structure [43]. Infrared radiation accounts for a large share of the solar energy distribution. Current solar water splitting devices generally consisting of a semiconductor as photocatalyst, mainly absorb ultraviolet (UV) radiation and only to a much smaller extend visible light (see Figure 4) [44]. Adapting the optical properties of a solar water splitting device to the solar spectrum is a great challenge. One recent approach to improve the performance of photoelectrodes is to take advantage of the low energy photons in the infrared (IR) range $[43,45]$. Some of these rare earth elements, e.g., lanthanum, erbium or ytterbium, have the capability to absorb light in the infrared region and to convert them into shorter wavelength photons via a so-called up-conversion process, which effectively enhances the overall light harvesting and 
photon management in the films [43]. For example, Zhang et al. attempted to exploit IR radiation, by casting a rare-earth element solution on top of hematite photoelectrodes [45]. Emission spectra evidence that the rare earth nanocrystals (RENs) in the composite absorb at around $980 \mathrm{~nm}$ and emit photons at 550 and $670 \mathrm{~nm}$. The emitted photons are absorbed by the surrounding hematite film, leading to a photocurrent enhancement from 25 to $130 \mathrm{nA} \mathrm{cm}^{-2}$ and thus to an improvement of water splitting efficiency. In another study, it is proposed that drop-casted ytterbium oxide on hematite nanorod photoelectrodes induces the formation of a passivating layer that accounts for the great photocurrent enhancement [46]. However, it might be that here, the photoabsorption enhancement effect via up-conversion also plays a role.

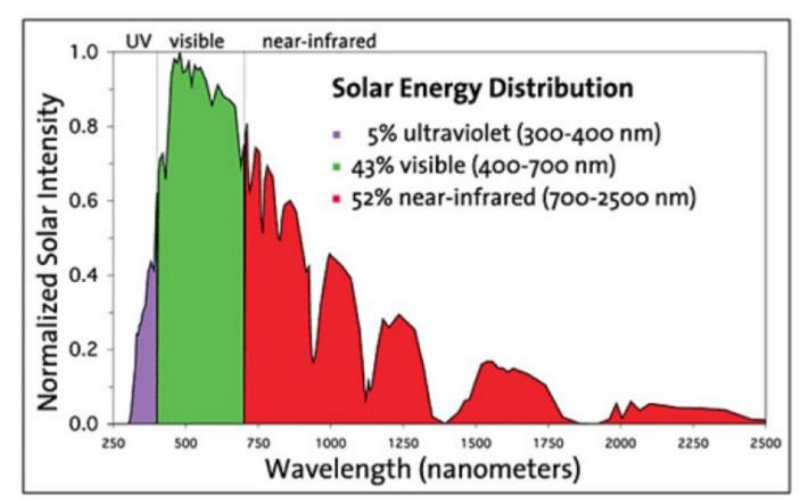

(a)

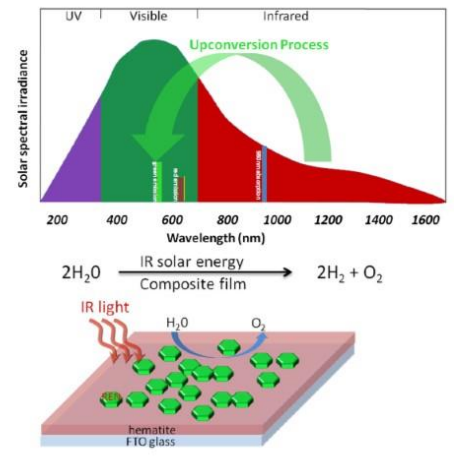

(b)

Figure 4. (a) Solar energy distribution and capture by a semiconductor photoabsorber; (b) mechanism of the up-conversion process (top) and enhanced solar water splitting performance by using near infrared radiation with the aid of rare earth materials (bottom). Reprinted from Reference [44].

\subsubsection{Surface Plasmonic Metal Decorated Hematite}

Surface plasmon polaritons (SPPs) are electromagnetic excitations coupled to the collective oscillations of free electrons on a metal surface, and thus can be considered to be surface electromagnetic waves propagating along the interface of a metal and a dielectric material [47]. The SPP electromagnetic field is confined to the vicinity of the metallodielectric boundary, resulting in a great field enhancement at the interface. For a plasmonic metal decorated semiconductor photoanode, the optical excitation of SPPs propagating at the nanostructured metallodielectic interface probably traps incident solar energy and transforms it into surface electromagnetic waves propagating along the photoelectrode surface, thus enhances the effective light path length as well as the absorption [47]. It probably also enhances solar absorption near the interface where the electromagnetic field is confined and amplified. Thus, SPPs are promising to overcome the dilemma of the requirement for hematite to be physically thin enough and optically thick enough for efficient solar energy-conversion.

In recent years, surface plasmonic nanostructures have been widely studied in enhancing the solar water splitting efficiency [48-50]. For example, the influence of gold nanoparticles on hematite photoanodes for solar water splitting was reported [49]. Only for electrode geometries with metal particles located at the semiconductor-electrolyte interface a relative enhancement was observed (see Figure 5) [49]. This is in agreement with the observation that minority carrier (holes) transport to the electrolyte is the most significant barrier to achieving high efficiencies in this system. In another study, three times higher light absorption and photocurrent improvement compared with the pristine hematite photoanodes are achieved from thin hematite films containing Au nanoparticles [50]. They found that the plasmonic enhancement goes along with an increase in the amount of Au nanoparticles for hematite films of constant thickness and is maximized for thin films. A thin hematite film can reduce the charge transport distance and have an optimal local field enhancement effect. The plasmonic resonance of metallic nanoparticles can also be adjusted through adjustment of the shapes or sizes to match the absorption bands of semiconductors [47]. It also strongly depends on the light incidence 
angle. The disadvantage of surface plasmonic metal decoration is the usage of noble metal, thus the high cost and low abundancy are critical issues.
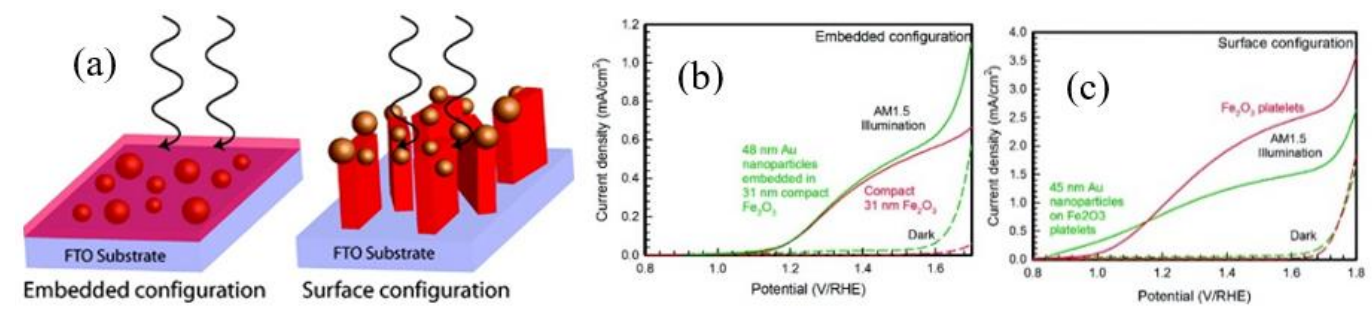

Figure 5. (a) Two different electrode configurations: Embedded and surface; (b) I-V curves for the embedded configuration and (c) I-V curves for the surface configuration. Reprinted with permission from reference [49], copyright (2011) American Chemical Society.

\subsection{Surface Passivation}

Even when using a nanostructured hematite combined with a surface incorporating oxygen evolution co-catalyst, a large overpotential is still required to drive water oxidation. This suggests that other factors besides slow OER kinetics or poor visible light absorption greatly affect the water splitting [42]. Surface states, also named interfacial states, are two-dimensional (2D) localized levels associated with the surface of hematite, which are caused by either oxygen vacancies or crystalline disorder [7,51]. Surface states are thought to be responsible for the recombination of photo-generated electron-holes before participating in the water oxidation reaction. However, they are also considered to transfer the photo-generated holes and accelerate the water oxidation reaction (see Figure 6) [51]. In order to improve charge separation at the hematite/electrolyte interface, introducing a surface passivation layer is an effective way to minimize the surface states. Representative surface passivation materials, such as $\mathrm{Al}_{2} \mathrm{O}_{3}$ [7,52,53], $\mathrm{Ga}_{2} \mathrm{O}_{3}$ [53], $\mathrm{In}_{2} \mathrm{O}_{3}$ [53], $\mathrm{ZnO}$ [54] and $\mathrm{TiO}_{2}$ [55,56], have shown significant photocurrent improvements and resulted in a cathodic shift of $\mathrm{V}_{\text {onset }}$ (see Table 3). These studies showed that advantageous surface modifications of hematite can be achieved by safe, inexpensive materials as well as simple processing techniques. Established preparation methods are spin coating, ALD, hydrothermal and chemical bath deposition. For example, Le Formal et al. coated nanostructured hematite photoanodes with a very thin ( 0.1 to $2 \mathrm{~nm}$ ) $\mathrm{Al}_{2} \mathrm{O}_{3}$ overlayer by ALD and found a significant decrease in the overpotential, due to the passivation of surface trapping states eliminating surface charge recombination [7,52]. Hisatomi et al. found that an $\mathrm{Al}_{2} \mathrm{O}_{3}, \mathrm{Ga}_{2} \mathrm{O}_{3}$, or $\mathrm{In}_{2} \mathrm{O}_{3}$ engineered overlayer created by facile chemical bath deposition can improve the $\mathrm{V}_{\text {onset }}$ of PEC water oxidation of hematite photoanodes [53]. These corundum-type overlayers were expected to release the lattice strain of the ultrathin hematite layer, reducing the surface state density. As revealed by transient absorption (TA) studies under applied bias, such cathodic shift of the $\mathrm{V}_{\text {onset }}$, coincides with a similar cathodic shift of the occurrence of long-lived photo-generated holes, was due to slower electron-hole recombination, and primarily attributed to enhanced electron depletion in hematite [15]. Xi et al. previously reported that a very thin $\mathrm{ZnO}$ overlayer deposited by spin-coating on the surface of a hematite film was found to enhance the photocurrent by more than $40 \%$ and to induce a cathodic $V_{\text {onset }}$ shift of $170 \mathrm{mV}$, compared to untreated hematite [54]. This improvement resulted from the altered $\mathrm{V}_{\mathrm{fb}}$ and reduced surface defects. Yang et al. reported that an ultrathin ALD-grown $\mathrm{TiO}_{2}$ overlayer on the hematite surface contributed to an obvious improvement in PEC water oxidation performance by cathodically shifting the $\mathrm{V}_{\text {onset }}$ up to $100 \mathrm{mV}$ [55]. With electrocatalytic or bulk doping effects ruled out, this PEC improvement was attributed to better charge separation, fewer surface charge recombination, and thus greater photovoltage induced by the $\mathrm{TiO}_{2}$ overlayer. A greater cathodic shift of $250 \mathrm{mV}$ in turn-on potential was achieved over hematite photoanodes with surface passivated by a $\mathrm{TiO}_{2}$ overlayer via an ALD method [56]. TA spectroscopy shows that the enhanced PEC responses of heterostructured photoanodes are mainly due to an enhanced charge separation. 
Table 3. List of materials and preparation methods used for surface passivation on hematite nanostructures.

\begin{tabular}{|c|c|c|c|c|c|c|}
\hline Passivation Materials & Preparation & Electrolyte & $\begin{array}{c}\text { Onset } \\
\text { Potential } \\
\left(\mathrm{V}_{\mathrm{RHE}}\right)\end{array}$ & $\begin{array}{c}\text { Onset } \\
\text { Potential } \\
\text { shift }(\mathrm{mV})\end{array}$ & $\begin{array}{c}\text { Photocurrent at } \\
1.23 \mathrm{~V}_{\mathrm{RHE}} \\
\left(\mathrm{mA} \mathrm{cm} \mathrm{cm}^{-2}\right)\end{array}$ & Ref. \\
\hline $\mathrm{Al}_{2} \mathrm{O}_{3}$ & CBD & $1 \mathrm{M} \mathrm{NaOH}$ & 0.91 & 200 & 0.4 & [52] \\
\hline $\mathrm{Al}_{2} \mathrm{O}_{3}$ & ALD & $1 \mathrm{M} \mathrm{NaOH}$ & 0.8 & 100 & 2.8 & [7] \\
\hline $\mathrm{Al}_{2} \mathrm{O}_{3}$ & ALD & $1 \mathrm{M} \mathrm{NaOH}$ & 0.97 & $\sim 90$ & $\sim 2.2$ & [53] \\
\hline $\mathrm{Ga}_{2} \mathrm{O}_{3}$ & CBD & $1 \mathrm{M} \mathrm{NaOH}$ & 0.8 & $\sim 210$ & $\sim 0.45$ & [52] \\
\hline $\mathrm{In}_{2} \mathrm{O}_{3}$ & $\mathrm{CBD}$ & $1 \mathrm{M} \mathrm{NaOH}$ & 0.89 & $\sim 100$ & $\sim 0.47$ & [52] \\
\hline $\mathrm{ZnAc}$ & Spin coating & $1 \mathrm{M} \mathrm{NaOH}$ & 0.76 & 170 & 1.08 & [54] \\
\hline $\mathrm{TiO}_{2}$ & ALD & $1 \mathrm{M} \mathrm{NaOH}$ & $\sim 0.9$ & 100 & 1.014 & [55] \\
\hline $\mathrm{TiO}_{2}$ & ALD & $1 \mathrm{M} \mathrm{NaOH}$ & 0.8 & $\sim 250$ & 2 & [56] \\
\hline $\mathrm{NaPO}_{2} \mathrm{H}_{2}$ & Decompose & $1 \mathrm{M} \mathrm{NaOH}$ & 0.7 & 100 & 1.1 & [57] \\
\hline CTAB & Hydrothermal & $1 \mathrm{M} \mathrm{KOH}$ & 0.6 & 0 & 0.45 & [58] \\
\hline
\end{tabular}
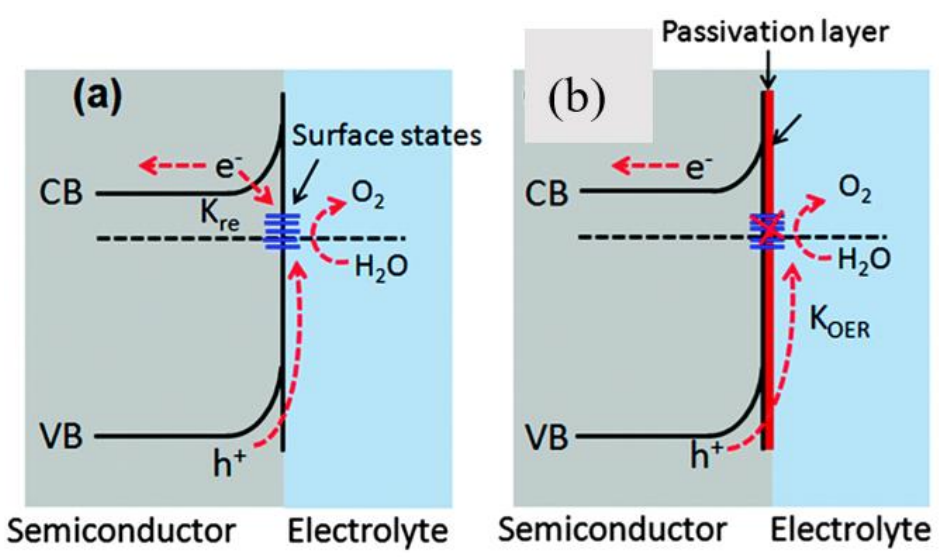

Figure 6. The band structures of an n-type semiconductor photoanode (a) without and (b) with a passivation layer. (a) High charge recombination happening at surface defects and thus inefficient water oxidation by the photo-generated holes; (b) use of thin non-catalytic passivation layers which suppress surface recombination and improve water oxidation. Adapted from Reference [14], copyright (2016) Royal Society of Chemistry.

Additionally, non-metal surface passivation of hematite using e.g., phosphorus [57], or bromide [58] were previously presented. It was shown that amorphous phosphorus is able to passivate surface states of a hematite nanorod photoanode and to suppress electron-hole recombination, significantly enhancing the photocurrent for water oxidation [57]. It is proposed that cetyltrimethylammonium bromide (CTAB) modification of the hematite surface leads to an increase of carrier density favoring the transport of the charge carriers [58]. The Br-layer induced negative electric field created on the hematite surface is assumed to speed up the interfacial charge transfer and the OER kinetics leading to an enhancement in the solar water splitting performance.

\subsection{Surface Chemical Etching}

Surface chemical etching, e.g., etching with $\mathrm{HF}$ [59], $\mathrm{HCl}[60,61]$ or $\mathrm{H}_{2}$ [62], can remove native and/or amorphous oxides and change the chemical state of the surface of the electrode, thus potentially improve the surface conductivity and photocurrent. Hematite is generally accepted to be kinetically stable under oxidizing conditions, hence surface etching may help to passivate surface states and facilitate the water oxidation at low applied potentials $[14,19]$. An HF treatment on hematite nanowires etches away the amorphous iron oxide phase at the surface, leading to a single crystalline surface and a reduction of the $\mathrm{V}_{\text {onset }}$ by $300 \mathrm{mV}$ [59]. Rioult et al. found that the $\mathrm{HCl}$ etching does not contribute any amorphous structure removal [60]. They found that partial $\mathrm{HCl}$ wet-etching has a great effect on the morphology of the hematite films, but also on the electronic structure and the oxidation state. Recently, $\mathrm{H}_{2}$-treated hematite nanostructures were deposited by a simple pyrolysis 
of sodium borohydride $\left(\mathrm{NaBH}_{4}\right)$ in a crucible [62]. The $\mathrm{H}_{2}$-treated photoanode showed more than 2.5 times photocurrent density enhancement and $120 \mathrm{mV}$ cathodic shift in the $\mathrm{V}_{\text {onset }}$ than that of the pristine hematite. The authors attributed the photocurrent increase to an increased number of oxygen vacancies, while they correlated the cathodic shift of the $\mathrm{V}_{\text {onset }}$ to the surface effect of $\mathrm{H}_{2}$ treatment. Using $\mathrm{CoF}_{3}$ aqueous solution as an etching agent for Ti-doped hematite photoelectrode was also reported [63]. The authors proposed that the adsorption of fluoride on the surface of the electrode shifts the $\mathrm{CB}$ to a more negative potential than the redox level of $\mathrm{H}_{2} / \mathrm{H}^{+}$. This allows the photo-generated electrons to directly reduce water to $\mathrm{H}_{2}$. There are also other etching agents to remove surface defects $[64,65]$. Table 4 summarizes recent surface etching works for hematite photoanodes.

Table 4. List of surface chemical etching for surface modification on hematite nanostructures. Note:

a directly oxidizing $\mathrm{Fe}$ foil in a $\mathrm{H}_{2}-\mathrm{O}_{2}$ flame at around $1700 \mathrm{~K}$.

\begin{tabular}{|c|c|c|c|c|c|c|}
\hline $\begin{array}{l}\text { Modification } \\
\text { Material }\end{array}$ & Preparation & Electrolyte & $\begin{array}{c}\text { Onset } \\
\text { Potential } \\
\left(\mathrm{V}_{\mathrm{RHE}}\right)\end{array}$ & $\begin{array}{c}\text { Onset } \\
\text { Potential } \\
\text { Shift (mV) }\end{array}$ & $\begin{array}{c}\text { Photocurrent at } \\
1.23 \mathrm{~V}_{\mathrm{RHE}} \\
\left(\mathrm{mA} \mathrm{cm}{ }^{-2}\right)\end{array}$ & Ref. \\
\hline HF & Dip in HF solution & $1 \mathrm{M} \mathrm{KOH}$ & $\sim 0.8$ & No data & $\sim 0.18$ & [59] \\
\hline $\mathrm{HCl}$ & Dip in $\mathrm{HCl}$ solution & $0.1 \mathrm{M} \mathrm{NaOH}$ & $\sim 1.0$ & 100 & $\sim 1.0$ & {$[60]$} \\
\hline $\mathrm{HCl}$ & Dip in $\mathrm{HCl}$ solution & $1 \mathrm{M} \mathrm{NaOH}$ & 0.87 & 100 & 1.5 & {$[61]$} \\
\hline $\mathrm{NaBH}_{4}$ & Pyrolysis by $\mathrm{NaBH}_{4}$ solution & $1 \mathrm{M} \mathrm{NaOH}$ & 0.87 & 120 & 2.28 & {$[62]$} \\
\hline $\mathrm{CoF}_{3}$ & Dip in $\mathrm{CoF}_{3}$ solution & $1 \mathrm{M} \mathrm{NaOH}$ & 0.6 & 200 & $\sim 1.5$ & [63] \\
\hline $\mathrm{H}_{2}-\mathrm{O}_{2}{ }^{\mathrm{a}}$ & React in a $\mathrm{H}_{2}-\mathrm{O}_{2}$ flame & $1 \mathrm{M} \mathrm{NaOH}$ & 0.50 & No data & $\sim 0.45$ & {$[64]$} \\
\hline Oxalic acid & Dip in oxalic acid solution & $\begin{array}{l}1 \mathrm{M} \mathrm{NaOH} \text { with and } \\
\text { without } \mathrm{H}_{2} \mathrm{O}_{2} \text { added }\end{array}$ & $\sim 0.7$ & $<20$ & $\sim 1.4$ & [65] \\
\hline
\end{tabular}

\subsection{Surface Doping}

Surface doping with metal ions is an alternative way to obtain an enhanced PEC performance of hematite photoanodes [14]. It possibly promotes charge migration, broadens the absorption range and/or creates a doped overlayer to catalyze the surface water oxidation reaction. Several studies demonstrated that surface-engineered hematite nanostructures with metal ion doping, e.g., $\mathrm{Sn}^{4+}$ [11], $\mathrm{Ni}^{3+}{ }^{4+}$ [66] or $\mathrm{Ag}^{+}$[7], exhibited a considerable photocurrent density enhancement and cathodic $\mathrm{V}_{\text {onset }}$ shifts [15] (see Table 5). Xi et al. treated hydrothermally grown iron oxyhydroxide nanorod arrays with $\mathrm{Sn}^{4+}$ aqueous solution before subsequently annealing it at high temperature [11]. The formation of a $\mathrm{Fe}_{\mathrm{x}} \mathrm{Sn}_{1-\mathrm{x}} \mathrm{O}_{4}$ thin layer on hematite nanorod arrays by surface $\mathrm{Sn}$ doping is assumed to passivate surface defects, thus to reduce electron-hole recombination at the interface of hematite-electrolyte, as well as to suppress the electron tunneling from the hematite core. Later, similar to this approach, a hematite nanotube photoanode doped with a thin $\mathrm{Ni}_{x} \mathrm{Fe}_{2-x} \mathrm{O}_{3}$ overlayer on the surface showed a $280 \%$ enhancement of the photoconversion efficiency compared to the pristine hematite nanotube film (see Figure 7) [66]. The authors proposed that the $\mathrm{Ni}_{x} \mathrm{Fe}_{2-x} \mathrm{O}_{3}$ overlayer was attributed to the facilitated charge migration, accelerated oxygen evolution, and avoiding the photoexcited hole recombination at the interface of hematite and electrolyte [14,66]. Recently, an $\mathrm{Ag}_{x} \mathrm{Fe}_{2-x} \mathrm{O}_{3}$ passivation layer with a thickness of 2-3 nm along hematite nanorods was reported for surface doping of $\mathrm{Ag}$ ions [67]. The authors claimed that the Ag-doped passivation layer increases the charge carrier density in the near-surface region and accelerates the kinetics of the surface oxidation reaction, synergistically contributing to the improved PEC performances. 


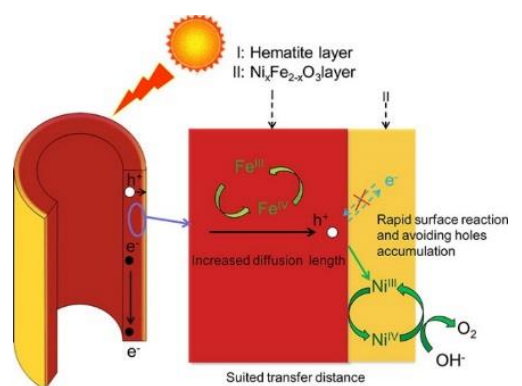

(a)

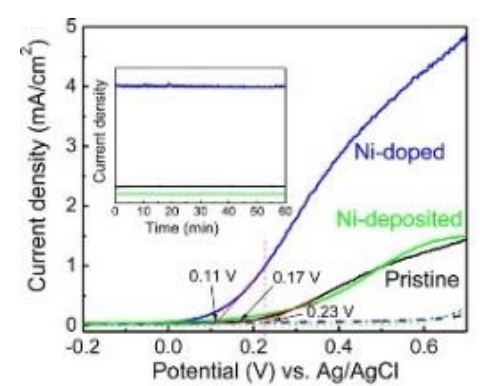

(b)

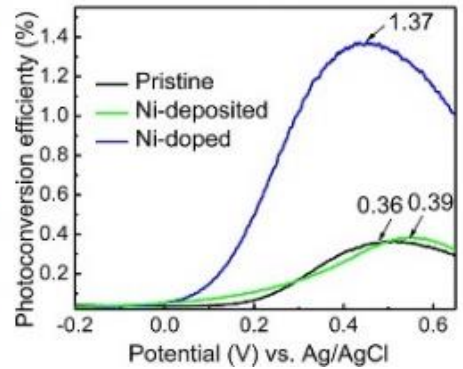

(c)

Figure 7. (a) Schematic of the OER process taking place at the hematite photoanode. In the sketch map, it only shows the OER process occurring on the outside surface of the hematite nanotube wall covered with the $\mathrm{Ni}_{x} \mathrm{Fe}_{2-\mathrm{x}} \mathrm{O}_{3}$ thin layer. The authors admitted that the same process also occurs on the inside surface; (b) current density (inset: Photochemical stability curves); and (c) incident photon-to-current conversion efficiency (IPCE) curves of the pristine, Ni-deposited and Ni-doped samples. Reprinted with permission from Reference [66], copyright (2012) American Chemical Society.

Table 5. List of surface doping for surface modification on hematite nanostructures.

\begin{tabular}{|c|c|c|c|c|c|c|}
\hline $\begin{array}{l}\text { Modification } \\
\text { Material }\end{array}$ & Preparation & Electrolyte & $\begin{array}{c}\text { Onset } \\
\text { Potential } \\
\left(V_{\text {RHE }}\right)\end{array}$ & $\begin{array}{c}\text { Onset } \\
\text { Potential } \\
\text { Shift }(\mathrm{mV})\end{array}$ & $\begin{array}{c}\text { Photocurrent at } \\
1.23 \mathrm{~V}_{\mathrm{RHE}} \\
\left(\mathrm{mA} \mathrm{cm} \mathrm{cm}^{-2}\right)\end{array}$ & Ref. \\
\hline $\begin{array}{l}\mathrm{Sn}^{4+} \text { aqueous } \\
\text { solution }\end{array}$ & $\begin{array}{l}\text { Drop the solution on top and then } \\
\text { anneal at high temperature }\end{array}$ & $1 \mathrm{M} \mathrm{NaOH}$ & 0.62 & 100 & 2.25 & [11] \\
\hline $\begin{array}{l}\mathrm{Ni}^{2+} \text { aqueous } \\
\text { solution }\end{array}$ & $\begin{array}{l}\text { Electrodeposit and then anneal at } \\
\text { high temperature }\end{array}$ & $1 \mathrm{M} \mathrm{KOH}$ & $\sim 1.0$ & 100 & $\sim 1.0$ & [66] \\
\hline $\begin{array}{l}\mathrm{Ag}^{+} \text {aqueous } \\
\text { solution }\end{array}$ & $\begin{array}{l}\text { Dip in the } \mathrm{Ag}^{+} \text {solution, dry and } \\
\text { then anneal at high temperature }\end{array}$ & $\begin{array}{l}0.5 \mathrm{M} \mathrm{NaCl} \\
\quad(\mathrm{pH} 6.7)\end{array}$ & 0.40 & 100 & $\sim 0.1$ & [67] \\
\hline
\end{tabular}

\section{Conclusions and Outlook}

Due to its moderate band gap, chemical stability, non-toxicity, abundance, and low cost, hematite is a promising photoelectrode material for solar water splitting. However, it suffers from poor charge transfer and separation ability, short hole diffusion length as well as slow water oxidation kinetics. Several surface modification methods have been developed to improve slow water oxidation kinetics and the range of light absorption in the past decade. In this review, several of these surface modification techniques were reviewed. They include loading of co-catalysts, decorating with rare earth metal oxides or surface plasmonic metal oxides to enhance photoabsorption, applying a surface passivation layer, surface chemical etching and surface doping. Although significant progress in surface modification has been made, continuous innovations and new studies of surface modification using operando methods, e.g., UV-Vis, XAS, XPS and SEM are essential to meet the request for the development of efficient photoanodes using hematite and to drive the solar water splitting into practical application. In particular, future studies are highly demanded to explore new surface modification materials and methods [42,68]. A limited material and method selection may not meet the demands for obtaining highly efficiency solar water oxidation devices. We prospect that in the near future, a combination of different modification strategies, as well as nanostructure and semiconductor engineering, may greatly help to generate strong synergistic effects for further PEC performance improvement [15].

Funding: This work was fully supported by the Helmholtz Association (VH-NG-1140).

Conflicts of Interest: The authors declare no conflict of interest.

\section{References}

1. Walter, M.G.; Warren, E.L.; McKone, J.R.; Boettcher, S.W.; Mi, Q.; Santori, E.A.; Lewis, N.S. Solar water splitting cells. Chem. Rev. 2010, 110, 6446-6473. [CrossRef] [PubMed] 
2. Santos, D.M.F.; Sequeira, C.A.C.; Figueiredo, J.L. Hydrogen production by alkaline water electrolysis. Química Nova 2013, 36, 1176-1193. [CrossRef]

3. Yang, J.H.; Wang, D.G.; Han, H.X.; Li, C. Roles of cocatalysts in photocatalysis and photoelectrocatalysis. Acc. Chem. Res. 2013, 46, 1900-1909. [CrossRef] [PubMed]

4. Xi, L.F.; Schwanke, C.; Zhou, D.; Drevon, D.; van de Krol, R.; Lange, K.M. In situ XAS study of CoBi modified hematite photoanodes. Dalton Trans. 2017, 46, 15719-15726. [CrossRef] [PubMed]

5. Sivula, K.; Le Formal, F.; Grätzel, M. Solar water splitting: Progress using hematite $\left(\alpha-\mathrm{Fe}_{2} \mathrm{O}_{3}\right)$ photoelectrodes. ChemSusChem 2011, 4, 432-449. [CrossRef] [PubMed]

6. Murphy, A.B.; Barnes, P.R.F.; Randeniya, L.K.; Plumb, I.C.; Grey, I.E.; Horne, M.D.; Glasscock, J.A. Efficiency of solar water splitting using semiconductor electrodes. Int. J. Hydrogen Energy 2006, 31, 1999-2017. [CrossRef]

7. Le Formal, F.; Tetreault, N.; Cornuz, M.; Modehl, T.; Grätzel, M.; Sivula, K. Passivating surface states on water splitting hematite photoanodes with alumina overlayers. Chem. Sci. 2011, 2, 737-743. [CrossRef]

8. Chen, Z.; Jaramillo, T.F.; Deutsch, T.G.; Kleiman-Schwarsctein, A.; Forman, A.J.; Gaillard, N.; Garland, R.; Takanabe, K.; Heske, C.; Sunkara, M.; et al. Accelerating materials development for photoelectrochemical hydrogen production: Standards for methods, definitions, and reporting protocols. J. Mater. Res. 2010, 25, 3-16. [CrossRef]

9. Tilley, S.D.; Cornuz, M.; Sivula, K.; Grätzel, M. Light-induced water splitting with hematite: Improved nanostructure and iridium oxide catalysis. Angew. Chem. Int. Ed. 2010, 49, 6405-6408. [CrossRef] [PubMed]

10. Ling, Y.; Wang, G.; Wheeler, D.A.; Zhang, J.Z.; Li, Y. Sn-doped hematite nanostructures for photoelectrochemical water splitting. Nano Lett. 2011, 11, 2119-2125. [CrossRef] [PubMed]

11. Xi, L.F.; Chiam, S.Y.; Mak, W.F.; Tran, P.D.; Barber, J.; Loo, S.C.J.; Wong, L.H. A novel strategy for surface treatment on hematite photoanode for efficient water oxidation. Chem. Sci. 2013, 4, 164-169. [CrossRef]

12. Sivula, K.; Le Formal, F.; Grätzel, M. $\mathrm{WO}_{3}-\mathrm{Fe}_{2} \mathrm{O}_{3}$ photoanodes for water splitting: A host scaffold, guest absorber approach. Chem. Mater. 2009, 21, 2862-2867. [CrossRef]

13. Wang, K.X.; Yu, Z.; Liu, V.; Brongersma, M.L.; Jaramillo, T.F.; Fan, S. Nearly total solar absorption in ultrathin nanostructured iron oxide for efficient photoelectrochemical water splitting. ACS Photonics 2014, 1, 235-240. [CrossRef]

14. Tamirat, A.G.; Rick, J.; Dubale, A.A.; Su, W.N.; Hwang, B.J. Using hematite for photoelectrochemical water splitting: A review of current progress and challenges. Nanoscale Horiz. 2016, 1, 243-267. [CrossRef]

15. Shen, S.; Lindley, S.A.; Chen, X.; Zhang, J.Z. Hematite heterostructures for photoelectrochemical water splitting: Rational materials design and charge carrier dynamics. Energy Environ. Sci. 2016, 9, 2744-2775. [CrossRef]

16. Wu, H.Y.; Ren, F.; Xing, Z.; Zheng, X.D.; Wu, L.; Jiang, C.Z. Cathodic shift of onset potential for water oxidation of $\mathrm{WO}_{3}$ photoanode by $\mathrm{Zr}^{+}$ions implantation. J. Appl. Phys. 2017, 121, 085305. [CrossRef]

17. Ling, Y.; Li, Y. Review of Sn-doped hematite nanostructures for photoelectrochemical water splitting. Part. Part. Syst. Charact. 2014, 31, 1113-1121. [CrossRef]

18. Zhang, Y.; Ji, H.; Ma, W.; Chen, C.; Song, W.; Zhao, J. Doping-promoted solar water oxidation on hematite photoanodes. Molecules 2016, 21, 868. [CrossRef] [PubMed]

19. Liu, R.; Zheng, Z.; Spurgeon, J.; Yang, X. Enhanced photoelectrochemical water-splitting performance of semiconductors by surface passivation layers. Energy Environ. Sci. 2014, 7, 2504-2517. [CrossRef]

20. Badia-Bou, L.; Mas-Marza, E.; Rodenas, P.; Barea, E.M.; Fabregat-Santiago, F.; Gimenez, S.; Peris, E.; Bisquert, J. Water oxidation at hematite photoelectrodes with an iridium-based catalyst. J. Phys. Chem. C 2013, 117, 3826-3833. [CrossRef]

21. Li, W.; Sheehan, S.W.; He, D.; He, Y.; Yao, X.; Grimm, R.L.; Brudvig, G.W.; Wang, D. Hematite-based solar water splitting in acidic solutions: Functionalization by mono- and multilayers of iridium oxygen-evolution catalysts. Angew. Chem. Int. Ed. 2015, 54, 11428-11432. [CrossRef] [PubMed]

22. Majumder, S.A.; Khan, S.U.M. Photoelectrolysis of water at bare and electrocatalyst covered thin film iron oxide electrode. Int. J. Hydrogen Energy 1994, 19, 881-887. [CrossRef]

23. Fan, K.; Li, F.; Wang, L.; Daniel, Q.; Chen, H.; Gabrielsson, E.; Sun, J.; Sun, L. Immobilization of a molecular ruthenium catalyst on hematite nanorod arrays for water oxidation with stable photocurrent. ChemSusChem 2015, 8, 3242-3247. [CrossRef] [PubMed] 
24. Chen, X.; Ren, X.; Liu, Z.; Zhuang, L.; Lu, J. Promoting the photoanode efficiency for water splitting by combining hematite and molecular Ru catalysts. Electrochem. Commun. 2013, 27, 148-151. [CrossRef]

25. Zhang, M.; Luo, W.; Li, Z.; Yu, T.; Zou, Z. Surface modification of hematite photoanode films with rhodium. Rare Met. 2011, 30, 38-41. [CrossRef]

26. Warwick, M.E.A.; Barreca, D.; Bontempi, E.; Carraro, G.; Gasparotto, A.; Maccato, C.; Kaunisto, K.; Ruokozmo, T.-P.; Lemmetyinen, H.; Sada, C.; et al. Pt-functionalized $\mathrm{Fe}_{2} \mathrm{O}_{3}$ photoanodes for solar water splitting: The role of hematite nano-organization and the platinum redox state. Phys. Chem. Chem. Phys. 2015, 17, 12899-12907. [CrossRef] [PubMed]

27. Kanan, M.W.; Nocera, D.G. In situ formation of an oxygen-evolving catalyst in neutral water containing phosphate and $\mathrm{Co}^{2+}$. Science 2008, 321, 1072-1075. [CrossRef] [PubMed]

28. Seabold, J.A.; Choi, K.S. Effect of a cobalt-based oxygen evolution catalyst on the stability and the selectivity of photo-oxidation reactions of a $\mathrm{WO}_{3}$ photoanode. Chem. Mater. 2011, 23, 1105-1112. [CrossRef]

29. Pijpers, J.J.; Winkler, M.T.; Surendranath, Y.; Buonassisi, T.; Nocera, D.G. Light-induced water oxidation at silicon electrodes functionalized with a cobalt oxygen-evolving catalyst. Proc. Natl. Acad. Sci. USA 2011, 108, 10056-10061. [CrossRef] [PubMed]

30. Zhong, D.K.; Sun, J.; Inumaru, H.; Gamelin, D.R. Solar water oxidation by composite catalyst $/ \alpha-\mathrm{Fe}_{2} \mathrm{O}_{3}$ photoanodes. J. Am. Chem. Soc. 2009, 131, 6086-6087. [CrossRef] [PubMed]

31. Klahr, B.; Gimenez, S.; Fabregat-Santiago, F.; Bisquert, J.; Hamann, T.W. Photoelectrochemical and impedance spectroscopic investigation of water oxidation with "Co- $\mathrm{P}_{\mathrm{i}}$ "-coated hematite electrodes. J. Am. Chem. Soc. 2012, 134, 16693-16700. [CrossRef] [PubMed]

32. Xi, L.F.; Bassi, P.S.; Chiam, S.Y.; Mak, W.F.; Tran, P.D.; Barber, J.; Chye Loo, J.S.; Wong, L.H. $\mathrm{Co}_{3} \mathrm{O}_{4}$-decorated hematite nanorods as an effective photoanode for solar water oxidation. J. Phys. Chem. C 2012, 116, 13884-13889. [CrossRef]

33. Wang, G.; Ling, Y.; Lu, X.; Zhai, T.; Qian, F.; Tong, Y.; Li, Y. A mechanistic study into the catalytic effect of $\mathrm{Ni}(\mathrm{OH})_{2}$ on hematite for photoelectrochemical water oxidation. Nanoscale 2013, 5, 4129-4133. [CrossRef] [PubMed]

34. Hong, Y.R.; Liu, Z.; Al-Bukhari, S.F.; Lee, C.J.; Yung, D.L.; Chi, D.; Hor, T.S. Effect of oxygen evolution catalysts on hematite nanorods for solar water oxidation. Chem. Commun. 2011, 47, 10653-10655. [CrossRef] [PubMed]

35. Halaoui, L. Photoelectrochemical investigation of the mechanism of enhancement of water oxidation at the hematite nanorod array modified with "NiB ${ }^{\prime}$ ". J. Phys. Chem. C 2016, 120, 22766-22776. [CrossRef]

36. Young, K.M.; Hamann, T.W. Enhanced photocatalytic water oxidation efficiency with $\mathrm{Ni}(\mathrm{OH})_{2}$ catalysts deposited on $\alpha-\mathrm{Fe}_{2} \mathrm{O}_{3}$ via ALD. Chem. Commun. 2014, 50, 8727-8730. [CrossRef] [PubMed]

37. Malara, F.; Minguzzi, A.; Marelli, M.; Morandi, S.; Psaro, R.; Santo, V.D.; Naldoni, A. $\alpha-\mathrm{Fe}_{2} \mathrm{O}_{3} / \mathrm{NiOOH}$ : An effective heterostructure for photoelectrochemical water oxidation. ACS Catal. 2015, 5, 5292-5300. [CrossRef]

38. Yang, X.; Du, C.; Liu, R.; Xie, J.; Wang, D. Balancing photovoltage generation and charge-transfer enhancement for catalyst-decorated photoelectrochemical water splitting: A case study of the hematite/ $\mathrm{MnO}_{\mathrm{x}}$ combination. J. Catal. 2013, 304, 86-91. [CrossRef]

39. Deng, J.; Lv, X.; Zhang, H.; Zhao, B.; Sun, X.; Zhong, J. Loading the FeNiOOH cocatalyst on Pt-modified hematite nanostructures for efficient solar water oxidation. Phys. Chem. Chem. Phys. 2016, 18, 10453-10458. [CrossRef] [PubMed]

40. Xu, D.; Rui, Y.; Li, Y.; Zhang, Q.; Wang, H. Zn-Co layered double hydroxide modified hematite photoanode for enhanced photoelectrochemical water splitting. Appl. Surf. Sci. 2015, 358, 436-442. [CrossRef]

41. Selvaraj, S.; Moon, H.; Kim, D.H. Combined effect of nano-structured $\mathrm{NiCo}_{2} \mathrm{~S}_{4}$ coated hematite photoanodes for efficient photoelectrochemical water oxidation. Catal. Today 2018, in press. [CrossRef]

42. Kuang, Y.; Yamada, T.; Domen, K. Surface and interface engineering for photoelectrochemical water oxidation. Joule 2017, 1, 290-305. [CrossRef]

43. Leduc, J.; Gönüllü, Y.; Raauf, A.; Fischer, T.; Mathur, S. Rare-earth-containing materials for photoelectrochemical water splitting applications. In Semiconductors for Photocatalysis; Mi, Z., Wang, L., Jagadish, C., Eds.; Elsevier Inc.: Amsterdam, The Netherlands, 2017; Volume 97, pp. 185-215. [CrossRef]

44. Enhance Solar Water Splitting Performance by Utilizing Near Infrared Radiation with Composite Films of Hematite and Rare Earth Doped Upconversion Materials. 2012. Available online: http:/ /icam-i2cam.org/ images/uploads /Zhang_Presentation.pdf (accessed on 22 July 2018). 
45. Zhang, M.; Lin, Y.; Mullen, T.J.; Lin, W.-F.; Sun, L.-D.; Yan, C.-H.; Patten, T.E.; Wang, D.; Liu, G.-Y. Improving hematite's solar water splitting efficiency by incorporating rare-earth upconversion nanomaterials. J. Phys. Chem. Lett. 2012, 3, 3188-3192. [CrossRef] [PubMed]

46. Cots, A.; Gómez, R. Ytterbium modification of pristine and molybdenum-modified hematite electrodes as a strategy for efficient water splitting photoanodes. Appl. Catal. B 2017, 219, 492-500. [CrossRef]

47. Liu, R.; Yang, X.; Anfuso, C.L.; Huang, Z.; Han, L. Plasmonic $\alpha-\mathrm{Fe}_{2} \mathrm{O}_{3}$ photoanodes for solar water splitting. Rev. Adv. Sci. Eng. 2014, 4, 1-9. [CrossRef]

48. Zhang, L.; Hermann, L.O.; Baumberg, J.J. Size dependent plasmonic effect on $\mathrm{BiVO}_{4}$ photoanodes for solar water splitting. Sci. Rep. 2015, 5, 16660. [CrossRef] [PubMed]

49. Thimsen, E.; Le Formal, F.; Grätzel, M.; Warren, S.C. Influence of plasmonic Au nanoparticles on the photoactivity of $\mathrm{Fe}_{2} \mathrm{O}_{3}$ electrodes for water splitting. Nano Lett. 2011, 11, 35-43. [CrossRef] [PubMed]

50. Archana, S.A.; Pachauri, N.; Shan, Z.C.; Pan, S.L.; Gupta, A. Plasmonic enhancement of photoactivity by gold nanoparticles embedded in hematite films. J. Phys. Chem. C 2015, 119, 15506-15516. [CrossRef]

51. Shinde, P.S.; Choi, S.H.; Kim, Y.; Ryu, J.; Jang, J.S. Onset potential behavior in $\alpha-\mathrm{Fe}_{2} \mathrm{O}_{3}$ photoanodes: The influence of surface and diffusion Sn doping on the surface states. Phys. Chem. Chem. Phys. 2016, 18, 2495-2509. [CrossRef] [PubMed]

52. Hisatomi, T.; Le Formal, F.; Cornuz, M.; Brillet, J.; Tétreault, N.; Sivula, K.; Grätzel, M. Cathodic shift in onset potential of solar oxygen evolution on hematite by 13-group oxide overlayers. Energy Environ. Sci. 2011, 4, 2512-2515. [CrossRef]

53. Le Formal, F.; Sivula, K.; Grätzel, M. The transient photocurrent and photovoltage behavior of a hematite photoanode under working conditions and the influence of surface treatments. J. Phys. Chem. C 2012, 116, 26707-26720. [CrossRef]

54. Xi, L.F.; Bassi, P.S.; Chiam, S.Y.; Mak, W.F.; Tran, P.D.; Barber, J.; Chye Loo, J.S.; Wong, L.H. Surface treatment of hematite photoanodes with zinc acetate for water oxidation. Nanoscale 2012, 4, 4430-4433. [CrossRef] [PubMed]

55. Yang, X.; Liu, R.; Du, C.; Dai, P.; Zheng, Z.; Wang, D. Improving hematite-based photoelectrochemical water splitting with ultrathin $\mathrm{TiO}_{2}$ by atomic layer deposition. ACS Appl. Mater. Interfaces 2014, 6, 12005-12011. [CrossRef] [PubMed]

56. Barreca, D.; Carraro, G.; Gasparotto, A.; Maccato, C.; Warwick, M.E.A.; Kaunisto, K.; Sada, C.; Turner, S.; Gönüllü, Y.; Ruoko, T.-P. $\mathrm{Fe}_{2} \mathrm{O}_{3}-\mathrm{TiO}_{2}$ nano-heterostructure photoanodes for highly efficient solar water oxidation. Adv. Mater. Interfaces 2015, 2, 1500313. [CrossRef]

57. Xiong, D.; Li, W.; Wang, X.; Liu, L. Passivation of hematite nanorod photoanodes with a phosphorus overlayer for enhanced photoelectrochemical water oxidation. Nanotechnology 2016, 27, 37. [CrossRef] [PubMed]

58. Li, Q.; Antony, R.P.; Wong, L.H.; Ng, D.H.L. Promotional effects of cetyltrimethylammonium bromide surface modification on a hematite photoanode for photoelectrochemical water splitting. RSC Adv. 2015, 5, 100142-100146. [CrossRef]

59. Chernomordik, B.D.; Russell, H.B.; Cvelbar, U.; Jasinski, J.B.; Kumar, V.; Deutsch, T.; Sunkara, M.K. Photoelectrochemical activity of as-grown, $\alpha-\mathrm{Fe}_{2} \mathrm{O}_{3}$ nanowire array electrodes for water splitting. Nanotechnology 2012, 23, 194009. [CrossRef] [PubMed]

60. Rioult, M.; Belkhou, R.; Magnan, H.; Stanescu, D.; Stanescu, S.; Maccherozzi, F.; Rountree, C.; Barbier, A. Local electronic structure and photoelectrochemical activity of partial chemically etched Ti-doped hematite. Surf. Sci. 2015, 641, 310-313. [CrossRef]

61. Cao, D.; Luo, W.; Feng, J.; Zhao, X.; Li, Z.; Zou, Z. Cathodic shift of onset potential for water oxidation on a $\mathrm{Ti}^{4+}$ doped $\mathrm{Fe}_{2} \mathrm{O}_{3}$ photoanode by suppressing the back reaction. Energy Environ. Sci. 2014, 7, 752-759. [CrossRef]

62. Li, M.; Deng, J.; Pu, A.; Zhang, P.; Zhang, H.; Gao, J.; Hao, Y.; Zhong, J.; Sun, X. Hydrogen-treated hematite nanostructures with low onset potential for highly efficient solar water oxidation. J. Mater. Chem. A 2014, 2, 6727-6733. [CrossRef]

63. Hu, Y.-S.; Kleiman-Shwarsctein, A.; Stucky, G.D.; McFarland, E.W. Improved photoelectrochemical performance of Ti-doped $\alpha-\mathrm{Fe}_{2} \mathrm{O}_{3}$ thin films by surface modification with fluoride. Chem. Commun. 2009, 2652-2654. [CrossRef] [PubMed] 
64. Han, J.; Zong, X.; Wang, Z.; Li, C. A hematite photoanode with gradient structure hows an unprecedentedly low onset potential for photoelectrochemical water oxidation. Phys. Chem. Chem. Phys. 2014, 16, 23544-23548. [CrossRef] [PubMed]

65. Cho, I.S.; Han, H.S.; Logar, M.; Park, J.; Zheng, X.L. Enhancing low-bias performance of hematite photoanodes for solar water splitting by simultaneous reduction of bulk, interface, and surface recombination pathways. Adv. Energy Mater. 2016, 6, 1501840. [CrossRef]

66. Cheng, W.; He, J.; Sun, Z.; Peng, Y.; Yao, T.; Liu, Q.; Jiang, Y.; Hu, F.; Xie, Z.; He, B.; et al. Ni-doped overlayer hematite nanotube: A highly photoactive architecture for utilization of visible light. J. Phys. Chem. C 2012, 116, 24060-24067. [CrossRef]

67. Shen, S.; Zhou, J.; Dong, C.L.; Hu, Y.; Tseng, E.N.; Guo, P.; Guo, L.; Mao, S.S. Surface engineered doping of hematite nanorod arrays for improved photoelectrochemical water splitting. Sci. Rep. 2014, 4, 6627. [CrossRef] [PubMed]

68. Xi, L.F.; Wang, F.; Schwanke, C.; Abdi, F.F.; Golnak, R.; Fiechter, S.; Ellmer, K.; van de Krol, R.; Lange, K.M. In situ structural study of $\mathrm{MnP}_{\mathrm{i}}$ modified $\mathrm{BiVO}_{4}$ photoanodes by soft X-ray absorption spectroscopy. J. Phys. Chem. C 2017, 121, 19668-19676. [CrossRef]

(C) 2018 by the authors. Licensee MDPI, Basel, Switzerland. This article is an open access article distributed under the terms and conditions of the Creative Commons Attribution (CC BY) license (http://creativecommons.org/licenses/by/4.0/). 